'This extract is taken from the author's original manuscript and has not been edited.

The definitive, published, version of record is available here:

https://www.palgrave.com/gp/book/9783319717753 


\section{Indigenous People, Resistance and Racialised Criminality}

Racism and racial discrimination is a common experience for many Indigenous people. Recent Australian research found that, depending in which state they lived, between one in three and one in four Aboriginal and Torres Strait Islander people identified experiencing racial discrimination over the previous two years in a range of areas from abuse in public places to denial of access to goods and services, including employment and housing (Allison et al., 2012; Cunneen et al., 2014; Schwartz et al., 2013). Racism has material outcomes (in the denial of goods and services) and further entrenches social and economic marginalisation. It can directly contribute to Indigenous anger and criminal offending (Day et al., 2008: 98) and has specific effects on poorer physical and mental health, including increased psychological distress, depression and anxiety (Paradies et al., 2008: 3). Racism and discrimination is an ongoing manifestation of the historically excluded position of Indigenous people as colonised peoples. It is the active denial of the humanity of the affected person and their collective cultural identity, with negative impacts on political, economic, social and emotional wellbeing (Paradies et al., 2008:6).

This chapter focusses on one particular aspect of racism: the ways in which racialised criminality is both constructed and reproduced in the media. I focus specifically on racialised criminality and Indigenous peoples in Australia. The chapter takes a broad approach to media and includes mainstream media outlets (both print and television) and other media forms including social media and film. It looks at both non-Indigenous and Indigenous media, the latter being particularly important in understanding Indigenous resistance and challenges to mainstream representations. We have argued elsewhere that criminalisaton and penality are part of the relations of power which produce and reproduce racialised social relations (Cunneen et al., 2013). The criminal justice system constitutes social groups as threats and reproduces a society built on racialised boundaries. Indeed, processes of criminalisation and penality constitute a significant racialising discourse - that is we understand 'race' through discourses about crime and punishment (black men as violent; Indigenous culture as criminogenic) and we understand crime and punishment through images of race (for example, the dominant cultural image of the violent offender/prisoner as being young, male and from a minority background). The media convey various representations of criminalisation and penality and it is this role of the media (in its various contradictory ways) that is the centre of this chapter. The chapter focusses on a number of areas including reporting of Indigenous deaths in custody, reporting on riots and the growing use of social media as a means of constructing racialised criminality. Finally, the chapter considers the growth of Indigenous and alternative media in challenging mainstream representations of Indigenous people and crime.

\section{Reporting Deaths in Custody}

The Royal Commission into Aboriginal Deaths in Custody (RCIADIC) (Johnston, 1991) was one of the most comprehensive inquiries held into the situation of Indigenous peoples in Australia. The Royal Commission investigated 99 Indigenous deaths in police, prison and juvenile justice custody during the period 1980 to 1989 and made widespread recommendations relating to the criminal justice system and social, economic and political affairs more generally. The establishment of the Royal Commission was the result of a long national campaign by Indigenous people (Wootten, 1991). In the lead-up to the Royal Commission, investigative journalism played an important part in raising questions about the causes of Indigenous deaths in custody and the failure of authorities to respond to those 
deaths. As Bacon (2005: 23) notes, 'Mayman won a Golden Walkley, Australia's highest journalism award, for an investigation of John Pat's death published in The Age [and] ABC's Four Corners team took up the story and also won a Walkley award for their report'.

This critical role of the media in the establishment of the RCIADIC was acknowledged by the Commission:

By its coverage of the issues, from the death of John Pat to that of Lloyd Boney, by placing them in their broader social and moral context, and by its presentation of the campaign of the Committee to Defend Black Rights, the media has acted as one of the protagonists in the process of achieving greater justice for Aboriginal people that is the goal of this Commission (Johnston, 1991: (2) 185).

However, the Royal Commission noted that this progressive role by sections of the media was overshadowed by more problematic approaches. The far more common media approach was to either ignore Indigenous issues completely, or when they were reported upon to treat Indigenous people as a 'problem', that is, to represent 'Aboriginal people as a dissident, disruptive, or criminal element' (Johnston, 1991: (2)186). The Royal Commission noted the increase in the use of the word 'riot' in relation to confrontations involving Aboriginal people during the late 1980s. An analysis conducted for the Commission of the Sydney Morning Herald from January 1987 to April 1990 (the period the RCIADIC was investigating deaths and coincidentally also covering the 1988 Australian Bicentennial celebrations) showed that 40 per cent of all references to the word 'riot' within Australia were related to Aboriginal people (Johnston, 1991: (2)186).

Other research around this time confirmed the strong association between Indigenous people and crime and disorder. In an examination of newspaper reporting about youth in Western Australia between 1990 and 1992, Sercombe (1995) found that the major issue reported in relation to young people was crime. However, the 'face' of youth crime was also heavily racialised. Some 85 per cent of stories that referred to Aboriginal youth were principally about crime (Sercombe, 1995:78). A media study for the Australian Human Rights Commission's National Inquiry into Racist Violence revealed that 38 per cent of newspaper articles which mentioned Redfern during 1988 and 1989 were articles which were 'stereotypically negative stories' about Aboriginal people (Jakubowicz, 1990:18). Within these stories, the largest subject category identified Aboriginal people with crime and violence. A study of newspaper reporting in northwest NSW (Cunneen, 1987) found that the major daily newspaper in the area (the Daily Liberal) engaged in discriminatory reporting: Aboriginal people were the only identifiable group who had their ethnicity or racial background mentioned in newspaper reports on crime: the only 'offenders' who were linguistically marked and separated by 'race' were Indigenous people. Thus analysis of various media confirmed the association of Indigenous people with crime, criminality, irrationality and riots (see also Goodall, 1993). The National Inquiry into Racist Violence also raised a number of issues relating to the media portrayal of Aboriginal people.

Discriminatory reporting in relation to crime stories was cited as being particularly likely to generate a climate conducive to racist violence. Terms such as 'black terror' or 'black crime wave' clearly convey a sense of racial hostility and threat... Aborigines in many rural areas complained that local media reinforced racist attitudes and generated fear and tension in their reporting of race issues (HREOC, 1991:357). 
By contrast, analysis of newspaper reporting of Indigenous deaths in custody in the period following the RCIADIC showed that many deaths were not reported upon at all, and when they were reported on the stories were brief, often less than 100 words (Bacon, 2005: 32). This is despite the fact that Indigenous deaths in custody remains a significant problem. The number of Indigenous deaths increased during the 1990s after the RCIADIC.

Notwithstanding a decline during the early 2000s, the number of Indigenous deaths in custody has again increased (Lyneham and Chan, 2013: xviii). One of the few in-depth media investigations of deaths in custody in recent years has not appeared in the mainstream media, but rather in the independent online news service Crikey. Inga Ting (2011), in an eleven-part series of articles, investigated 132 coronial inquests into deaths in NSW prison custody between 2001 and 2009. Many of these involved the deaths of Indigenous prisoners. She discovered that prisoners were still dying in custody from the same failed practices that the RCIADIC had sought to eliminate. Ting found that coronial investigations documented more than 60 cases in which 'bureaucratic bungling, a failure or absence of policy, breaches of procedure or lack of communication between government agencies contributed to the death' (Ting, 2011:2). Many of the deaths occurred because custodial or health staff failed to adequately screen inmates, failed to consult inmate's medical and other files, failed to transfer files or failed to communicate important information about prisoner's health and safety. As a result, in many cases prisoners died because of incompetence or neglect. Their deaths 'could have been avoided had custodial and health authorities exercised proper duty of care and adhered to policies implemented as a result of Royal Commission recommendations' (Ting, 2011:2). The work of independent investigative journalists, like Ting, stands in contrast to the relative silence around deaths in custody found in the mainstream media.

\section{The Media, Deaths in Custody and Indigenous Resistance}

Of particular importance is not only the silence of the mainstream media around deaths in custody, but the factors that appear to pique media interest. The moment when the mainstream media becomes interested in deaths in custody is when there are Indigenous protests (usually referred to as riots by the media) after a death has occurred. While the events and circumstances surrounding deaths in custody appear of little interest to the media, this changes dramatically if there are public protests concerning those deaths. Indigenous resistance to policing, imprisonment and deaths in custody in Australia is recast through the mainstream media and the criminal justice system as instances of racialised criminality. Indigenous resistance is represented as lawless and the political dimension of resistance is denied. Representing Indigenous resistance to colonial power as 'criminal' has a long history in Australia, and rests on particular racialised assumptions about Indigenous people as being without law and civilisation, and the nature of the Australian state being founded in discovery and settlement, rather than through invasion.

The violence of the colonial state, both historically and contemporaneously through deaths in custody, is recast as the colonial state upholding law and order against rioting and lawless 'natives'. Goodall's (1993) analysis of the Brewarrina protests and 'riot' after the death in custody of Lloyd Boney in 1987 showed that television footage of the events was cut and repeatedly re-used in such a way as to show Aboriginal people as irrational and criminal. The televised message had a powerful symbolic meaning well beyond any aim to simply report 'what happened'. Similar issues can be seen in coverage of the Redfern and Palm Island 'riots' discussed in more detail below. 


\section{Redfern Riot 2004}

The riot in Redfern in February 2004 occurred after the death of TJ Hickey. Seventeen year old ' $\mathrm{TJ}$ ' had died after impaling himself on a metal fence whilst riding his bicycle in the inner Sydney suburb of Redfern. On the night following his death a serious riot erupted in Redfern between Aboriginal people and police which caused widespread injury. At the time of TJ's death there was a police operation in the vicinity arising from an earlier assault and robbery which had allegedly involved an Aboriginal offender. A number of vehicle patrols were active in the area at the time, and one had followed TJ although he was not a 'person of interest' in relation to the robbery. There was a widespread belief at the time that TJ was being chased by police at the time of his death, and indeed the Coroner subsequently found that TJ's death was a death in custody, occurring as it did during police operations.

The subsequent riot after TJ's death received widespread publicity, with various 'causes' discussed by media and politicians. There were a group of common explanations and solutions to the riot which dominated the public domain. One set of explanations used motivational causes for rioting behaviour such as drugs, alcohol, and hot weather. Another set of explanations blamed social disadvantage. And the third set of explanations blamed the lack of effective policing in the area. These explanatory narratives have been used previously to account for anti-police riots in Redfern (Cunneen, 1990).

One explanation put forward by police, politicians and media commentators was that the riot was caused by drugs. According to a source from Redfern police, the heroin trade was the 'true cause' of the riot and poor relations with police because of a police crackdown on the heroin trade in Redfern (Sydney Morning Herald, 17 May 2004). Similarly, an editorial in The Australian stated simply, 'the riot was caused by heroin' (18 May 2004). Other reports blamed a 'softly, softly' approach to policing in Redfern (Sydney Morning Herald, 18 February 2004). Alternatively, the 'Block' (an area in Redfern where many Aboriginal people live) was portrayed as a no-go area, with the only solution being to increase the number of police and the number of street patrols (Sydney Morning Herald, 24 February 2004). Both these explanations saw the cause of the riot as a failure of an inadequate police presence.

The question of disadvantage and the lack of 'hope' for people in Redfern was also a theme: summarised in the newspaper heading 'Kids Need Hope, Assistance and Education' (Sydney Morning Herald, 22 February 2004). It was common in this narrative for police to 'blame' other government departments for their lack of support in Redfern. The assumption was that if young people had educational and employment opportunities then there would be no rioting behaviour. In the months following the riot there was a strong emphasis on increasing police capabilities in Redfern. The building of a new $\$ 6$ million seven story police station was announced. Police numbers in Redfern were increased by one third from 170 to 226, and a new riot squad (the Operational Support Group) was formed. In relation to social policy, the Redfern Waterloo Partnership Project was further strengthened and funded.

Virtually no attention was paid in these official explanations to the long history of volatile conflict between Aboriginal people and the police in Redfern. Instances of police abuse of Aboriginal people, first documented by the New South Wales Council for Civil Liberties, date back to the 1960s. In the early 1970s the first Aboriginal Legal Service in Australia was established in Redfern because of police harassment of Aboriginal people in the area. By the mid to late 1980s riots between police and Aboriginal young people were relatively common 
(Cunneen, 1990). An investigation by the Federal Race Discrimination Commission in 1990 over the use of tactical response police in raids around the 'Block' found that the police used excessive force and that the justifications for the raids exhibited institutional racism. Some local police were found to refer to Redfern as 'coon county' (Cunneen, 1990:11).

The death of TJ Hickey sparked a riot, but did so in the context of constant complaints of police harassment, particularly of Aboriginal youth. Part of this harassment derived from a renewed focus on 'zero tolerance' style police operations and the use of public order legislation that clearly targeted young people. The fact that TJ was classified as a 'High Risk Offender' by police meant that he was subject to constant scrutiny. His bail requirement not to visit a particular housing area where his mother resided almost certainly imposed a condition that he would constantly breach. The 2004 riot in Redfern was a clear case of moral indignation and collective protest against what was seen to be police involvement in the death of a young Indigenous boy. It demonstrated the depth of collective anger at the way the justice system operates. Yet the media representations of the riot provided no context or discussion of this sense of injustice. Indeed, the apparent lawlessness of Indigenous people lent itself well to the arguments for a greater police presence in the area. The fact that policing might be part of the problem was erased from public policy consideration.

\section{Palm Island Riot 2004}

Thirty six year old Mulrunji Doomadgee died in police custody on Palm Island in November 2004. He had been arrested for drunk and disorderly behaviour. He was healthy man when arrested and was not known as a trouble-maker on the Island, and had not been previously arrested on the Island. The riot occurred a week after Mulrunji's death, when the results of the autopsy became known to the community. The post-mortem examination revealed that Mulrunji suffered four broken ribs, a ruptured spleen and that his liver was almost cleaved in two.

The riot which occurred on Palm Island was clearly a protest against what was seen at the time as police involvement in the death of Mulrunji. During the protest, the local police station was set on fire, and the courthouse extensively damaged. As a result of the riot, the Queensland government established a Palm Island Select Committee. The terms of reference for the Committee did not include an examination of policing on the Island, but rather local government arrangements, infrastructure development and options to improve the coordination of government services on the Island. The government developed a Five Point Plan for Palm Island. The first point and 'absolute priority' was the restoration of law and order on the Island. The other four points included re-establishing services, rebuilding infrastructure (the first of which was to build a new police station and courthouse), the development of an alcohol management plan (to restrict access to alcohol) and to establish new governance arrangements.

The dominant view presented by government was the social and economic 'problems' of Palm Island led to the riot. The rioters were seen as lawless with media depictions such as a 'war zone', 'rioting mobs' and 'rioters... in a rampage' (Porter, 2015:292). However, people on Palm Island were also seen passive victims of disadvantage. Newspaper reports of Palm Island such as 'Tropic of Despair: Decades of oppression have the people of beautiful Palm Island dispirited and desperate' (Sydney Morning Herald, 4 December 2004: 31) reinforced this view. There are serious social and economic issues on Palm Island including unemployment, over-crowded housing and poor health. Yet the basic cause of the riot was a 
death in police custody where there was a strong community belief that police were directly responsible for the death. Contrary to dominant view of 'despair', the riot on Palm Island can also be interpreted as the community standing-up assertively and clearly expressing its outrage at the death of Mulrunji, and what it saw to be an attempted cover-up by the authorities.

Indeed, the community's anger was vindicated by the Coronial report. The State Coroner found that Mulrunji had punched Sergeant Hurley after being arrested and transported to the police station, and that Hurley had punched Mulrunji in response. Both men fell to the ground and Hurley lost his temper and hit Mulrunji several times after falling to the floor. 'I conclude that these actions of Senior Sergeant Hurley caused the fatal injuries' (Clements, 2006: 27). The Coroner found that the decision to arrest Mulrunji for drunk and disorderly could easily have been addressed by means other than arrest. According to the Coroner, the arrest was an inappropriate use of police discretion. In other words, Mulrunji should never have been in police custody in the first place.

The Coroner was critical of the failure to check on the health of Mulrunji after the fall and the assault.

Mulrunji cried out for help from the cell after being fatally injured, and no help came. The images from the cell video tape of Mulrunji, writhing in pain as he lay dying on the cell floor, were shocking and terribly distressing to family and anyone who sat through that portion of the evidence. The sounds from the cell surveillance tape are unlikely to be forgotten by anyone who was in court and heard that tape played. There is clear evidence that this must have been able to be heard from the police station dayroom where the monitor was running. Indeed, the timing of Senior Sergeant Hurley's visit to the cell suggests that the sounds were heard. But the response was completely inadequate and offered no proper review of Mulrunji's condition or call for medical attention. The inspections were cursory and dangerous even had Mulrunji been merely intoxicated. The so called arousal technique of nudging Mulrunji with a foot is not appropriate. It cannot be sanctioned (Clements, 2006: 32).

After it was suspected that Mulrunji was dead, there was no attempt at resuscitation. The Coroner was highly critical of the investigation which failed to meet the standards of thoroughness, competency or impartiality. One investigating officer was a friend of Hurley the police officer most likely to be under investigation.

In an important analysis of media representation of Indigenous people in Australia, Porter (2015) has contrasted the way mainstream media in Australia portrayed the riots on Palm Island after the death of Mulrunji Doomadgee with the portrayal of the riots in Ferguson, Missouri after the police shooting of Michael Brown: a contrast in portrayal between riotous (Palm Island) and righteous (Ferguson) behavior. As Porter (2015: 294) notes the disturbances in Ferguson are contextualised within a framework of civil disobedience, political demonstrations and the civil rights movement, while the event is placed more generally within the US history of Jim Crow and institutional racism. In contrast, the people of Palm Island are depicted as 'rioters' and therefore lack legitimacy to their claims. 'Indigeneity was portrayed as itself being synonymous with criminality... The police and media were constructed as victims, focusing on the fear and terror felt by these parties' (Porter, 2015: 292). The media construction of the events created suitable scapegoats and 'justified the state's heavy-handed response that follows' (Porter, 2015: 294). 
The problems identified by the RCADIC in media representations of Indigenous people and criminality have not abated. Indeed, in the twenty-five years since the Royal Commission it is commonplace for Indigenous people to be constantly framed within a discourse of criminality - a point highlighted by the relative neglect of deaths in custody except when there is community outrage and protests over specific deaths. In these cases Indigenous protests are recast as examples of lawlessness and criminality.

\section{Racism and Social Media}

Social media has provided an important medium for Indigenous groups and supporters. For example, the Facebook groups like the Indigenous Human Rights Network and Australians against Aboriginal Racism and Forced Land Acquisition advocate and promote the awareness of Indigenous human rights in Australia. The social media platform Indigenous $X$ began life as a Twitter account founded by Indigenous teacher Luke Pearson in 2012 with over 18,000 followers. Indigenous $X$ has expanded to Facebook, Instagram and YouTube, and a partnership with The Guardian Australia. However, social media has also been used to flame racial tensions and denigrate Aboriginal people. ABC reporter Norman Hermant (2015) has noted that when the ABC posts stories about Indigenous justice on Facebook, 'the flood gates open'. In this instance, Hermant had written a number of stories on an Amnesty International report which was critical of the levels of juvenile detention of Indigenous young people in Australia. The stories were posted on the ABC News Facebook page. Hermant details some of the many comments that were posted from people across Australia, including the following:

'White man built this country up and made it what it is today. What has ANY aboriginal ever built?? The laws is meant for all Australians as equals, but then that's why you don't like it, and you don't like it, the bush is wide open and waiting for you. Hey, you can go walk-about and just keep walking.'

'Well, if we start summery (sic) executions for these crimes they won't need to go to jail.'

'They can practice their war dances in prison.'

Hermant (2015) notes that the comments 'expose an uncomfortable reality many of us prefer to ignore. After reading these comments, and hearing from my colleagues at ABC Online, it's hard to conclude anything but this: the racially charged and hostile opinions expressed in these comments are not marginal.' They also reflect a long running trope of colonial ideology within Australia, namely that Indigenous people are a racially inferior, crime-prone group who require either incarceration or removal - themes which are repeated below in the discussion of a local 'anti-crime' Facebook group.

\section{The Townsville Crime Alerts and Discussion Facebook Group}

The Townsville Crime Alerts and Discussions (TCAD) are an active online Facebook group using social media to promote and lobby for more punitive approaches to law and order particularly focusing on harsher penalties for [Indigenous] juveniles. The Facebook page was created in 2012 and at October 2016 had nearly 35,000 members. Townsville has an estimated population of 180,000 . The TCAD have successfully organised petitions and protests, and received considerable media attention (for example, ABC News, 2013; Gillham, 
2013; SBS, 2014). Their primary message is that current legislation does not allow for 'young criminals' to be punished adequately for serious crimes, and that laws need to be toughened.

The Facebook group's founder, Ms Parkinson, personally met with then Premier, Campbell Newman and Mr Bleijie, the then Attorney-General. She was specifically referred to during the second reading of new punitive juvenile justice legislation. It was noted that the TCAD was 'very much in favour of the government's actions on youth offending' (Queensland Parliament, 2014: 596). Parkinson claimed that the reforms would not have occurred without the pressure of the TCAD (Anderson, 2014). The State Government's draconian youth justice reforms at the time included, among other changes, removing the principle of juvenile detention as a sanction of last resort, introducing 'naming and shaming' of young offenders, mandatory boot camps for repeat offenders, and the abolition of both the Indigenous Murri Youth Court and the court-ordered Youth Justice Conferencing program. In 2014 a splinter Facebook group, the Townsville Crime Alerts and Discussions Without Hitler Admin, was established. It is generally more extreme and overtly racist than the TCAD. It currently has over 3,000 members.

Some posts on these Facebook pages explicitly refer to 'ATSI' (a generally unacceptable abbreviation of Aboriginal and Torres Strait Islander people) and many refer specifically to Indigenous young people; others, while not explicitly referencing Indigenous people, post photos which makes it clear who is being discussed in the posts. Overwhelmingly the posts are highly derogatory, referring to young people allegedly involved in offences as 'pieces of crap', 'ATSI ferals', 'scum bags' and 'pieces of shit'. A perhaps well-rehearsed litany of complaints include lenient judges and magistrates, 'holiday camp' detention centres, and the lack of tough legislation. However, it is the racialised heart of the Facebook posts which is most pronounced and provides a deeper symbolic colonialist resonance to various claims such as 'the only thing that is going to deter these mongrels is a bullet', or calls to train dogs to attack Indigenous young people, or the need to bring the army onto the streets and allow them 'to use any force should they come across trouble' as one post stated. Images on the site, such as the one reproduced below, condone and legitimise violence. In this atmosphere, vigilante responses are hardly surprising. When an Indigenous man was reported in the local media to have been attacked by a group of masked men, racially taunted and then impaled on a fence (McMahon, 2016), many of the Facebook posts either doubted the veracity of the claim or thought the injured man had committed an offence and was therefore deserving of the response.

\section{[insert graphic about here]}

Facebook groups condoning vigilante violence against Indigenous people are not restricted to the TCAD. Similar Facebook groups can be found in the Northern Territory (NT) and Western Australia (WA). Facebook groups in Kalgoorlie WA became the focus of attention recently after the death of a 14 year old Aboriginal boy in August 2016. Elijah Doughty was killed when struck by a vehicle driven by the owner of a motorcycle the boy had allegedly stolen. The driver was charged with manslaughter. Following a protest outside the courthouse which turned violent, Aboriginal community members blamed Facebook groups and social media for inflaming racial tensions in the town (Bembridge, 2016). Kalgoorlie has a population of about 30,000 with the two main Facebook groups having about 18,000 members. Prior to Elijah Doughty's death the two Facebook groups were full of similar posts to those found on the TCAD - a focus on crime and Aboriginal people and various appeals to 
vigilante action. Some of the posts included: 'There is going to be revenge of some sort very soon!'; 'How many human bodies would it take to fill the mineshafts around Kalgoorlie? A: We're one theft closer to finding out!'; 'Feel free to run the oxygen thieves off the road if you see them'; 'We need a vigilante, like The Punisher'; 'Things will never change unless there is annual cull'; and, 'Everyone talks about hunting down these sub human mutts, but no one ever does' (cited in Purtill, 2016).

After Elijah's death, posts included 'Condolences to the driver trying to get his bike back. Went a bit to far' and another by same person 'I have more sympathy for the ute driver than I do for a thieving little scrote who was on the wrong place at the wrong time' (cited in Graham, 2016), and 'Good job you thieving bastard. Don't think you'll be touching another bike anytime soon ahaha. About time someone took it into their own hands hope it happens again' (cited in Purtill, 2016). Both Facebook groups have now been closed.

\section{Andrew Bolt and Hate Speech}

At the other end of the spectrum to the Facebook groups discussed above are the more institutionalised attacks on Indigenous people. Well known media commentator Andrew Bolt crosses over the use of mainstream and social media with a newspaper column, television program and blog site. The blog site in particular facilitates not only Bolt's attacks on Indigenous people, but opens up a site where unrestrained racist response from contributors proliferate (for example see Bolt, 2009).

In 2011 Andrew Bolt was brought before the Federal Court of Australia for breaching s18C of the Racial Discrimination Act. The section of the Act makes it unlawful to 'offend, insult, humiliate or intimidate' a person because of their 'race, colour or national or ethnic origin'. Bolt has used his position in the media for a considerable time to attack what he sees as 'light-skinned' Indigenous people who have no right to claim their Aboriginality and only do so because of a financial or other benefit (Langton, nd). Nine Aboriginal people took Bolt to court in relation to two articles he had written for the Herald Sun attacking 'light-skinned' Indigenous people.

The media commentator was found guilty. The Federal Court found that the articles were not written in good faith and contained factual errors. Bromberg $\mathrm{J}$ was 'satisfied that fair-skinned Aboriginal people... were reasonably likely... to have been offended, insulted, humiliated or intimidated by the imputations conveyed by the newspaper articles' (Eatock $v$ Bolt [2011] FCA 1103 at 17). Bromberg J was especially concerned with the 'intimidatory effect... in particular [on] young Aboriginal persons or others with vulnerability in relation to their identity' (Eatock $v$ Bolt at 24). Andrew Bolt, along with some conservative and ultra-right politicians, have campaigned for the repeal of s18C of the Racial Discrimination Act (see for example, Patel, 2016).

The growth of social media has allowed the representations of Indigenous racialised criminality to flourish, especially at a more localised level and largely without any form of moderation and regulation. Both the discussion by Hermant and the Bolt case also show that social media connected to mainstream media outlets allows the expression of a relatively unrestrained racism against Indigenous people. While the successful prosecution of Andrew Bolt related to pieces published in the Herald Sun, it is perhaps the public's response to his blogs which are more concerning. In commenting on the racism evident in public responses to the $\mathrm{ABC}$ Facebook stories on Indigenous people, Hermant notes that 'many of them list 
their names, where they live, even where they work on their Facebook accounts. They're not hiding'.

\section{Indigenous Media and Resistance}

A significant contribution to challenging representations of the racialised criminality of Indigenous people has been through the development of Indigenous media. This media takes various forms including newspapers, television, radio and film. Indigenous-run community radio dates back to the early 1970s and has developed now to over 130 community radio stations. In 1996 the National Indigenous Radio Service (NIRS) was established, providing a 24 hour-a-day service and an independent voice for Indigenous commentators nationwide on a range of issues including matters such as policing, over-representation in the criminal justice system and deaths in custody. Indigenous television dates back to 1988 with the establishment of Imparja in Alice Springs. National Indigenous Television (NITV) was established in 2007. Like the NIRS, NITV provides an important voice for Indigenous people. Its news service and current affairs programs regularly broadcast on Indigenous criminal justice matters. For example, Stan Grant's program, The Point, has investigations and analysis of topics such as Indigenous juveniles in detention, unsolved Indigenous murders, criminalisation and deaths in custody. A range of Indigenous operated newspapers (online and print) have also developed since the Koori Mail was established in 1991 and the National Indigenous Times in 2002. As Porter (2015: 299) noted in relation to the riots on Palm Island after the death of Mulrunji, 'Indigenous media was particularly critical of the labelling of all participants as 'rioters', and stressed the moral righteousness of Palm Islanders... In these ways, Indigenous media provided a powerful source in questioning misinformation within the mainstream media portrayal'.

Indigenous media has been important in providing alternative information on deaths in custody. In the case of the death of Julieka Dhu in Western Australia in 2014, NITV has provided extensive coverage and established a dedicated Facebook page. Twenty-two year old Ms Dhu died in a police watch house after being arrested for unpaid fines. Ms Dhu complained to police about severe pain, vomiting and partial paralysis and was twice taken to hospital but on both occasions was sent back to prison. On the third occasion she was taken to hospital she was dying from septicaemia and pneumonia. Police believed her transfer to hospital was not urgent and reportedly told nursing staff she was 'faking' her illness (Gartry and Trigger, 2015). At the time of writing, the coronial inquiry is yet to be completed.

Another medium through which Indigenous deaths in custody, imprisonment and criminal justice responses more generally have been explored by Indigenous people is through films such as Who Killed Malcolm Smith? (1992), Innocence Betrayed (2014) and Prison Songs (2015). Prison Songs focusses on inmates of Berrimah prison in the Northern Territory. Aboriginal people make-up over 80 per cent of the prison's population. The inmates share their stories through song. Kelrick Martin, the writer and director of the film, notes that, 'A lot of people in prison tend to be quite reflective, because they have a lot of time to think about where they've come from and how they've gotten where they are. The participants were therefore open to confronting their pasts and actions, and talking about it in an honest way' (Molloy, 2015). Innocence Betrayed (2014) follows the story of three families' search 
for justice after a botched police investigation and failed prosecution following the murders of three Aboriginal children in Bowraville, NSW in the early 1990s.

Who Killed Malcolm Smith? deals explicitly with Aboriginal deaths in custody. It was written and narrated by Richard Franklin. The film traces the story of Malcolm Smith from his early life, his removal from family and institutionalisation, and his subsequent imprisonment and death while in prison. Franklin helped investigate Smith's death for the Royal Commission into Aboriginal Deaths in Custody. In the film he narrates the story of Smith's life and death. Smith died from self-inflicted injuries after the handle of a paint brush had been driven into his left eye. While the facts concerning how Malcolm Smith died are relatively straightforward, the film explores the far more difficult question is why he died. Smith had been removed and isolated from his family at the age of 11 . He spent time 'in despotic institutions of various kinds [which] left him illiterate and innumerate, unskilled, and without experience of normal society' (Wootten, 1989).

After being made a state ward, Smith was first sent to Kinchela Boys' Home. After four years the Home's achievements were summarised in a manager's report which stated, 'taking into account Malcolm's lack of academic qualifications, being a persistent liar and his habits of perversion, it is difficult to be able to recommend anything for the future for him'. The film contrasts this view with what we know of Malcolm's early life before state intervention. There was no indication of ill treatment or unhappiness. The worst 'crimes' of eleven-yearold Malcolm were that he truanted from school and had gone joyriding on another child's bicycle.

The film traces the periods of Malcolm's imprisonment in Mt Penang Training Centre and then Tamworth Boys' Home, both described as para-military institutions designed to turn boys into 'automatons'. During the nine years and eight months of his adult life, Smith spent nine years in adult gaols, often as a result of prison sentences which were extremely harsh. It was during the period of his adult imprisonment that Malcolm's psychotic symptoms developed. Yet, no thorough psychiatric assessment was conducted, despite numerous serious attempts at self-injury. The film, following the Royal Commission report, argues that his particular death is part of a continuing legacy of the 'brutal cruelty of what was done in the name of protection and welfare by a smug, self-righteous and racist community'.

\section{Conclusion}

The 'media' is not a monolithic entity. There are times when investigative journalism by publicly owned media organisations, the ABC and SBS, has played an important role in uncovering injustices against Aboriginal people. This has been exemplified most recently by the ABC's 2016 Four Corners program exposing the abuse of children in detention in the Northern Territory. Indigenous media and alternative on-line media has also been important in providing a different discourse and voice for Indigenous people, particularly around deaths in custody and when there has been open conflict between Indigenous people and state authorities.

However, the dominant discourse in mainstream media presents a racialised view of criminality. The problems identified by the RCADIC in media representations of Indigenous people and criminality have not abated. Indeed, representations of racialised criminality have been popularized in new forms through the growth of social media. The widespread reach in local communities of Facebook shows the power of these mediums. Representations of 
Indigenous racialised criminality have flourished, largely without any form of moderation and regulation. Indeed, some posts on these Facebook sites call for or support vigilante violence against Indigenous people. Such depictions of Indigenous people as criminal, and the call for stronger state responses and the potential resort to violence, resonate with longer historical colonialist views of Aboriginal people as racially inferior and as a threat to property and social order.

\section{References}

ABC News (2013) 'Anti-crime group keen for youth curfew commitment', ABC News, 8 October 2013, http://www.abc.net.au/news/2013-10-08/anti-crime-group-keen-for-youthcurfew-commitment/5008908

Anderson, C. (2014) 'Online warriors fighting crime with the click of a mouse', Townsville Bulletin, 29 March 2014, http://www.townsvillebulletin.com.au/news/online-warriorsfighting-crime-with-the-click-of-a-mouse/story-fnjfzs4b-1226868519996

Allison, F., Cunneen, C., Schwartz, M. \& Behrendt, L. (2012) Indigenous Legal Needs Project: Northern Territory Report, Cairns: James Cook University,.

Bacon, W. (2005) 'A case study in ethical failure: twenty years of media coverage of Aboriginal deaths in custody’, Pacific Journalism Review, 11(2), pp.17 - 40.

Bembridge, C. (2016) 'Kalgoorlie Protest: Community Mourns as Elders Call for Action Against Online Racism' ABC News, 31 August 2016, http://www.abc.net.au/news/2016-0830/community-mourns-as-elders-call-for-justice-after-riot/7799942

Bolt, A. (2009) 'The New Tribe of White Blacks' Andrew Bolt Blog Posts, 21 August 2009. http://www.heraldsun.com.au/blogs/andrew-bolt/column--the-new-tribe-of-whiteblacks/news-story/2084e333d698f20fafd8b0a3f88c77b4

Clements, C. (2006) Inquest into the Death of Mulrunji, Brisbane: Office of the State Coroner.. <http://www.justice.qld.gov.au/courts/coroner/findings/mulrunji270906.doc $>$

Cunneen, C. (1987) 'Newspaper Reporting of Crime, Law and Order in North West NSW' Journal for Social Justice Studies, 2, pp.14-32.

Cunneen, C. (1990) Aboriginal/Police Relations in Redfern with Special Reference to the Police Raid of 8 February 1990. Report Commissioned by the National Inquiry into Racist Violence. Sydney: Human Rights and Equal Opportunity Commission.

Cunneen, C., Allison, F. \& Schwartz, M. (2014) Indigenous Legal Needs Project: Queensland Report, Cairns: James Cook University,.

Cunneen, C., Baldry, E., Brown, D., Brown, M., Schwartz, M. and Steel, A. (2013) Penal Culture and Hyperincarceration, London: Ashgate 
Day, A., Davey, L., Wanganeen, R., Howells, K., De Santolo J. and Nakata, M. (2008) 'The significance of context: Stories from South Australia', in A. Day, M. Nakata and K. Howells (eds), Anger and Indigenous Men, Leichhardt: Federation Press, pp. 88-102.

Gartry, L. and Trigger, R. (2015) 'Police thought dying woman Ms Dhu was faking it, coronial inquest told', ABC News. 23 November 2015. http://www.abc.net.au/news/2015-1123/inquest-into-death-of-dhu-in-police-custody/6963244.

Gillham, A. (2013) 'Townsville youth crime protesters get a hearing', ABC North Queensland, 26 February 2013. http://www.abc.net.au/local/photos/2013/02/26/3698793.htm

Goodall, H. (1993) 'Constructing a Riot: Television News and Aborigines', Media Information Australia, 68, pp.70-77

Graham, C. (2016) 'White Man's Manslaughter. Black Man’s Murder. White Man’s Riot. Black Man’s Uprising', New Matilda, 31 August 2016.

https://newmatilda.com/2016/08/31/the-kalgoorlie-uprising-a-rational-response-to-another$\underline{\text { black-death/ }}$

Human Rights and Equal Opportunity Commission (HREOC) (1991) Racist Violence, Report of the National Inquiry into Racist Violence, Canberra: AGPS.

Hermant, N. (2015) 'It doesn't take much to find Australia's racial divide on Facebook', The Drum, ABC News, 5 June 2015, http://www.abc.net.au/news/2015-06-05/hermant-exposingaustralias-racial-divide-on-facebook/6524358

Innocence Betrayed (2014), Director: Larissa Behrendt, Frontyard Films.

Jakubowicz, A. (1990) 'Racist Violence, Racism and the Media', Unpublished paper commissioned by the National Inquiry into Racist Violence, Sydney: Human Rights and Equal Opportunity Commission,.

Johnston, E. (1991) Final Report, Royal Commission into Aboriginal Deaths in Custody, Canberra: AGPS,.

Langton, M, (n.d.) The Nature of My Apology

http://www.abc.net.au/tv/qanda/pdf/Marcia_Langton_on_Bolt.pdf

Lyneham, M. and Chan, A. (2013) Deaths in Custody in Australia to 30 June 2011, Canberra: Australian Institute of Criminology.

McMahon, C. (2016) 'Man claims serious injuries behind racial attack from masked men', Townsville Bulletin, 2 June 2016. http://www.townsvillebulletin.com.au/news/man-claimsserious-injuries-behind-racial-attack-from-masked-men/newsstory/afeda78c89ce975430fe332e6ec617a1

Molloy, S. (2015) 'Prison Songs is the groundbreaking musical documentary filmed inside a Darwin jail', http://www.news.com.au/entertainment/tv/reality-tv/prison-songs-is-the- 
groundbreaking-musical-documentary-filmed-inside-a-darwin-jail/newsstory/c350469c9d9ee82bf79a78e2be7a03ca

Paradies, Y., Harris, R. and Anderson, I. (2008) The Impact of Racism on Indigenous Health in Australia and Aotearoa: Towards a Research Agenda, Discussion Paper No. 4, Darwin: Cooperative Research Centre for Aboriginal Health.

Patel, U. (2016) 'David Leyonhjelm, Malcolm Roberts push for Section 18C of Racial Discrimination Act to be Removed', ABC News, 7 August 2016.

http://www.abc.net.au/news/2016-08-07/leyonhjelm-roberts-tell-insiders-18c-racialdiscrimination-act/7698252

Porter, A. (2015) 'Riotous or Righteous Behaviour? Representations of Subaltern Resistance in the Australian Mainstream Media', Current Issues in Criminal Justice, 26(3), pp.289 304.

Prison Songs (2015), Director: Kelrick Martin, Spear Point Productions/Screen Australia.

Purtill, J. (2016) 'Racist. Violent. Deleted: The Facebook Posts Dividing Kalgoorlie', Triple J Hack, ABC Online, 1 September 2016. < http://www.abc.net.au/triplej/programs/hack/thefacebook-posts-dividing-kalgoorlie/7805346>

Queensland Parliament (2014) Record of Proceedings (Hansard), 18 March 2014. http://www.parliament.qld.gov.au/documents/hansard/2014/2014_03_18_WEEKLY.pdf

SBS (2014) New QLD laws aims to stop young offenders. SBS, 11 February 2014. http://www.sbs.com.au/news/article/2014/02/11/new-qld-laws-aim-stop-young-offenders

Schwartz, M., Cunneen, C. \& Allison, F. (2013) Indigenous Legal Needs Project: Victorian Report, Cairns: James Cook University.

Sercombe, H. (1995) 'The Face of the Criminal is Aboriginal', in J. Bessant, K. Carrington, and S. Cook, (eds) Cultures of Crime and Violence: The Australian Experience, Melbourne: La Trobe University Press.

Sydney Morning Herald (2004) 'Redfern riot blamed on heroin trade', Sydney Morning Herald, 17 May 2004. http:/www.smh.com.au/articles/2004/05/16/1084646071049.html

Sydney Morning Herald (2004) 'Redfern violence blamed on 'softly-softly' approach', Sydney Morning Herald, 18 February 2004.

http://www.smh.com.au/articles/2004/02/17/1076779978733.html

Sydney Morning Herald (2004) 'Time to start again, say Redfern police', Sydney Morning Herald, 24 February 2004. http://www.smh.com.au/articles/2004/02/23/1077497517473.html

Sydney Morning Herald (2004) 'Kids need hope, assistance and education', Sydney Morning Herald, 22 February 2004. http://www.smh.com.au/articles/2004/02/21/1077072890380.html 
Sydney Morning Herald (2004) 'Tropic of despair', Sydney Morning Herald, 4 December 2004. http://www.smh.com.au/news/National/Tropic-of-

despair/2004/12/03/1101923341699.html

The Australian (2004) 'The real racists are dealing drugs', The Australian, 18 May 2004.

Ting, I. (2011) Deaths in Custody, An Eleven Part Crikey Investigation, http://www.crikey.com.au/deaths-in-custody/

Who Killed Malcolm Smith? (1992), Directors: Adler, N and C. Sherwood, Film Australia/Titus Films.

Wootten, H. (1989) Report of Inquiry into the Death of Malcolm Charles Smith, Royal Commission into Aboriginal Deaths in Custody, Canberra: AGPS.

Wootten, H. (1991) '99 Reasons: The Royal Commission into Aboriginal Deaths in Custody' Polemic, 3(3).

\section{Cases}

Eatock v Bolt [2011] FCA 1103 (28 September 2011). 